Print ISSN: 2288-4637 / Online ISSN 2288-4645

doi:10.13106/jafeb.2018.vol5.no4.107

\title{
Online Brand Community and Its Outcomes*
}

\author{
Yongsoo $\mathrm{Ha}^{1}$
}

Received : September 15, 2018 Revised: October 10, 2018 Accepted: October 13, 2018

\begin{abstract}
The aim of this study is to delve deeper into the online brand community study. This study tests (a) the effects of online brand community on its outcomes, (b) the impact of value creation practice construct as a whole, (c) the effects of value creating practice construct on the two types of loyalty, loyalty toward the brand and the community. Participants of this study $(\mathrm{N}=353)$ are members of four types of online brand communities (e.g., business-to-consumer virtual product support community, firm-hosted online community, user-generated online community, peer-to-peer problem-solving community, and social media based brand community). Data were collected online using Amazon Mechanical Turk from April 10, 2016 to May 10, 2016. The data were analyzed through structural equations modeling using AMOS 20. The three community markers (e.g., consciousness of kind, rituals and traditions, and moral responsibility) and the four value creation practices (e.g., social networking, impression management, community engagement, and brand use) are proved to be significant indicators of online brand community and value creation practice constructs, respectively. Test results showed that strong and effective online brand communities generate value creation practices, and value creation practices enhance brand loyalty. The mediating effects of community loyalty between value creation practices and brand loyalty were revealed.
\end{abstract}

Keywords: Brand Loyalty, Community Markers, Community Loyalty, Online Brand Community.

JEL Classification Code: M10, M30, M31.

\section{Introduction}

As internet, social media, and mobile technologies have emerged, the last decade has seen a proliferation of online brand communities (Wirtz, Ambtman, Bloemer, Horvath, Ramaseshan, Klundert, Canli, \& Kandampully, 2013). Online brand community refers to a specialized, nongeographically bound, online group of consumers, based on social communications and relationships among brand's consumers (De Valck, Van Bruggen, \& Wierenga, 2009). Online brand community generates new and extended form of interactive consumer experiences. In online brand communities, consumers are actively engaged in interactive

* The present research has been conducted by the Research Grant of Kwangwoon University in 2018

1 First Author and Corresponding Author. Assistant Professor of Marketing, School of Business, Kwangwoon University, Korea [Postal Address: 20 Kwangwoon-ro, Nowon-gu, Seoul, 01897, South Korea] Tel.82-2-940-5645, Fax.82-2-940-8181,

E-mail: hys@kw.ac.kr processes through the online medium (Brodie, Ilic, Juric, \& Hollebeek, 2013).

The aim of this study is to delve deeper into the online brand community study by (a) testing the effects of online brand community on its outcomes, (b) testing the impact of value creation practice construct as a whole, (c) testing the effects of value creating practice construct on the two types of loyalty, loyalty toward the brand and the community.

\section{Literature Review}

\subsection{The Elements of Online Brand Community}

Consciousness of kind, rituals and traditions, and moral responsibility are the three core makrers of a brand community (Muniz \& O'Guinn, 2001). It is also found that the three community markers exist in both traditional, offline brand communities and computer-mediated, online brand communities (Muniz \& O'Guinn, 2001). 
Consciousness of kind is the shared intrinsic connection felt among community members (Gusfield, 1978), or a shared knowing of belonging (Weber, 1978). Legitimacy and oppositional loyalty are the social processes involved in perpetuating consciousness of kind. Legitimacy is a process that differentiates between true members of the community and those who are not (Muniz \& O'Guinn, 2001). Brand communities do not deny a membership. Anyone can be a member of the community regardless of ownership. However, although brand communities are generally open social organizations, they have status hierarchies. As opposed to true members who really know the brand, members who use the brand for wrong reasons are revealed by failing to appreciate the rituals and traditions, culture, history, and symbols of the community (Muniz \& O'Guinn, 2001). Oppositional loyalty also helps to maintain and strengthen consciousness of kind among members. Consumers use brand choices to mark both their inclusion and exclusion from various lifestyles (Hogg \& Savolainen, 1997). Oppositional loyalty serves to delineate what the brand is not, and who the brand community members are not through resistance to competing brands (Muniz \& O'Guinn, 2001).

Rituals and traditions are social processes that enable reproduction and transmission of meanings of the community (Muniz \& O'Guinn, 2001). Members celebrate the history of the brand and share brand stories. Appreciation of brand's history functions to differentiate between the true believers and the more opportunistic members (Holt, 1997). Sharing brand stories based on common consumption experiences reinforces consciousness of kind among members and links them together. These rituals and traditions contribute to the survival of brand cultures and their communities (Muniz \& O'Guinn, 2001). Rituals and traditions also act as a consumer agency for community members. The preservation of brand's meaning is important to brand community members. They often feel that they have a better understanding of the brand than the manufacturer does (Muniz \& O'Guinn, 2001). Rituals and traditions point to the social negotiation between marketers and consumer in constructing brand's meanings (Muniz \& O'Guinn, 2001).

Moral responsibility is a sense of duty to the community and individual members (Muniz \& O'Guinn, 2001). Muniz and O'Guinn (2001) revealed two critical and traditional communal missions in brand communities, both of which are based on moral responsibility; integrating and retaining members, and assisting brand community members in the proper use of the brand. Retaining old members and integrating new ones are a prime concern for the long-term survival of the community (Muniz \& O'Guinn, 2001). Members publicly posted a reminder to stay loyal to the brand and the community. Reasons for staying in the community are emphasized in computer-mediated communications as well. Most of the communications are centered on consumption experiences of using the focal brand as opposed to the competitors (Muniz \& O'Guinn, 2001). Those communications reinforce commitment and perpetuate loyalty both to the brand and the community (Muniz \& O'Guinn, 2001). Moral responsibility also induces community members to help each other in their consumption of the brand (Muniz \& O'Guinn, 2001). Members provide help and assist community "without thinking" because it seems like the "right thing to do" for them. Providing assistance is apparent in information sharing on brand-related resources (Muniz \& O'Guinn, 2001).

This study models the online brand community construct as a reflective first-order, formative second-order construct (Jarvis, Mackenzie, \& Podsakoff, 2003). The online brand community construct is modeled as having the three community markers as formative indicators, and the three community markers themselves are modeled as having reflective indicators.

\subsection{The Outcomes of Online Brand Community}

\subsubsection{Value Creation Practices}

In online brand communities, practice refers to discursive "know-that" knowledge. It is knowledge of what to say and do, and skills and projects which called "know-how" (Schau, Muniz, \& Arnould, 2009). Practices are explicit rules, instructions, principles, and precepts (Schau et al., 2009). When online brand community generates value creation practices (e.g., social networking, impression management, community engagement, and brand use practices), practices act as apprenticeships (Lave \& Wenger, 1991). Practices drive one another and work closely together as a process of collective value creation. Practices can be combined in complex ways. Interactions among practices can be either intra-thematic or inter-thematic. Within the brand community, practices are structurally reproduced and repeated, and members are systemically recruited to new practices (Schau et al., 2009).

Shau et al. (2009) suggested four thematic categories of value creation practices. Social networking practices related to the affective domains of the brand community and reinforce the social or moral bonds within the community. Practices such as welcoming, empathizing, and governing belong to this category. Welcoming greets new members and assists in their brand learning and community socialization. Through empathizing, members provide emotional and/or physical support to other members both for brand-related trials and non-brand-related issues. 
Governing clarifies the behavioral expectations within the brand community (Schau et al., 2009). Impression management practices have an outward focus and create favorable impressions of the brand community, brand enthusiasts, and the brand. Evangelizing and justifying belong to impression management practices. Evangelizing shares the focal brands' good news to inspire others. Justifying rationalizes the reasons for the devotion to the focal brand. Community engagement practices include staking, milestoning, badging, and documenting. Staking delineates members' specific domain of participation or engagement within the community. It marks intragroup distinction and similarity. Milestoning notes important events in brand ownership and consumption. Badging translates milestones into semiotic symbols. Documenting is a narrative of members' brand experiences which records in the brand relationship journey (Schau et al., 2009). Brand use practices include grooming, customizing, and commoditizing. Grooming is a practice that related to caring for the brand or systemizing the optimal use patterns. Customizing helps to modify the brand to suit group-level or individual needs. Commoditizing is a valenced behavior regarding marketplace. It distances from or approaches to the marketplace (Schau et al., 2009).

Practices generated in online brand community create value for both consumers and marketers, and it leads online brand community members to have heightened brand loyalty (Laroche, Habibi, Richard, \& Sankaranarayanan, 2012; Schau et al., 2009). Practices create value for consumers in that it allows members to achieve social identity and accrue cultural capital within the community (Schau et al., 2009). It also guides consumers to a proper use of the brand and provide them with an inexhaustible source of information. Practices create value for marketers as well. It fosters consumption opportunities, enhances brand perception, and heightens members' brand loyalty (Laroche et al., 2012; Schau et al., 2009). Participants in brand communities develop close relationships with the brand, the product, other consumers, and marketers through practices (Carroll \& Ahuvia, 2006). Practices facilitate and increase the levels of interaction between all elements of the brand community (McAlexander, Schouten, \& Koenig, 2002). Brand community members draw value from their interaction and build trust and loyalty toward the focal brand (Laroche et al., 2012).

Individuals achieve social identity in a community through self-awareness of membership in a group and the affective and evaluative significance of the membership (Bagozzi \& Dholakia, 2002). Practices provide members with opportunities to meet their desired social identity. Brand community behaviors frequently accompanied with a competitive spirit (Muniz \& O’Guinn, 2001). Members compete on brand devotion, knowledge, and history to express their competencies. As members possess expertise in complex practices, their standing and legitimacy increase in the community (Schau et al., 2009). Members develop both explicit performative skills and implicit cultural capital resources through the enactment of the practices. By demonstrating adroit performance on practices, members differentiate themselves with other members in terms of the social status within the community (Bourdieu, 1984; Holt, 1997). Consumers who achieve social status within the brand community are reluctant to abandon one's status (Schau et al., 2009). Members often stay engaged in the community because of the admiration of others even after they dispose of the focal brand (Schau et al., 2009).

Brand community members accrue cultural capital through the accumulation of numerous set of complex practices, and safeguard what they have accumulated (Schau et al., 2009). Cultural capital refers to social assets which promote social mobility beyond economic means (Bourdieu, 1984). Through engaging in practices, online brand community members develop cultural capital resources to differentiate their social status within the community (Holt, 1997; Schau et al., 2009). The pursuits of cultural capital are enacted in everyday brand community life. The accumulation of cultural capital increases the value member experiences from participating in the brand community (Schau et al., 2009).

Practices vitalize the brand community (Schau et al., 2009). Considering strong and effective online brand communities are built upon the three community markers (e.g., consciousness of kind, rituals and traditions, and moral responsibility) (Laroche et al., 2012), a strong and vibrant online brand community may generate diverse value creation pracitces. Thus, the first hypothesis of the study is that

H1: As online brand community strengthens, it will generate more value creation practices.

To test hypothesis 1 , this study models value creation practices as a reflective second-order construct. Social networking, impression management, community engagement, and brand use practices are modeled as reflective first-orders that constitute the second-order. By doing so, the effects of online brand community on value creation practice construct itself can be tested, rather than the effects on respective practices.

\subsubsection{Loyalty toward the Brand}

One of the primary goals of brand community is gaining loyal customers (McAlexander et al., 2002). Wirtz et al. 
(2013) found that online brand community engagements translate into brand loyalty. Online brand community members become loyal to the focal brand while identifying themselves with the community and interactively participating in it. When online brand community meets or exceeds members' expectation, members become satisfied with the community, and it directly affects brand loyalty (Wirtz et al., 2013). Loyalty behaviors in the online brand community could be different from those of traditional, offline brand community. For example, Brodie et al. (2013) stated that, because the online brand community is a powerful interactive engagement platform for the consumer-toconsumer recommendation, electronic word-of-mouth is one of predominant loyalty behaviors which could be found in online brand communities. Laroche et al. (2012) also found that online brand community based on social media has an ability to increase members' brand loyalty.

In light of this discussion, the present study hypothesizes that as strong online brand communities generate more value creation practices, community members engage in diverse value creation practices, and thus, it will enhance members' brand loyalty.

H2: As online brand community generates more value creation practices, members' brand loyalty will be enhanced.

\subsubsection{Loyalty toward the Community}

As it is shown in impression management practices, online brand community members work not only for a focal brand but also for a brand community. Group loyalty is a multifaceted construct. It is comprised of affective, cognitive, and behavioral factors (Levine \& Moreland, 2002). For example, emotionally, group loyalty could be manifested through the experience of positive emotions associated with a group membership. Cognitively, it could be manifested through depersonalized trust in group members, and optimism about the group's future. Behaviorally, group loyalty could be manifested through the sacrifices that members make to help their group. Staying in order to help the group even when they could receive better outcomes for themselves by leaving could be seen as an act of group loyalty (Levine \& Moreland, 2002; Van Vugt \& Hart, 2004). Based on group loyalty research, the present study models community loyalty as it consists of group identification (Bagozzi \& Dholakia, 2006a; Hinkle, Taylor, FoxCardamone, \& Crook, 1989), a sense of community (Rosenbaum, Ostrom, \& Kuntze, 2005), and organizational citizenship behavior (Podsakoff, Mackenzie, Moorman, \& Fetter, 1990).

Since people's identity is partly shaped by the social groups to which they belong (Tajfel \& Turner, 1986), people with high identification with their groups consider themselves as group members, while people with low identification consider themselves as unique individuals. Group identification increases members' perceived similarity to and liking for other members (Brewer \& Brown, 1998; Wilder, 1986). Social identity is the cornerstone of a group integrity which is the key to group survival (Arrow, McGrath, \& Berdahl, 2000). Van Vugt and Hart (2004) stated that social identity acts as a social glue, by holding groups together that would normally collapse due to a shortage of resources, and leads to group loyalty. Social identity can be established without any current reward or punishment, the expectation of future reciprocity, or even reputational acknowledgment among other group members (Dawes, Van de Kragt, \& Orbell, 1990).

McMillian and Chavis (1986) defined a sense of community as "a feeling of belonging, a belief that members matter to one another and to the overall group, and a shared faith that members' needs will be met through their commitment to be together". Individuals achieve a sense of community when they could obtain four benefits from joining a group; a feeling of belonging, a sense of mattering, integration and fulfillment of needs, and shared emotional connections among members (McMillian \& Chavis, 1986). Rosenbaum et al. (2005) revealed that a sense of community is a significant predictor of loyalty behavior. A sense of community generates emotional connections with the sponsoring organizations and prevent members from switching to competitor products or services (Rosenbaum et al., 2005).

Organizational citizenship behavior refers to discretional behaviors that are not part of members' formal role requirements, but nevertheless promote the effective functioning of the organization (Organ, 1988). Cooperation is one example of organizational citizenship behaviors that serves to maintain internal equilibrium. It induces spontaneous prosocial gestures to the needs of others. Cooperation is a product of informal organization such as brand communities (Muniz \& O'Guinn, 2001), which is derived from the logic of sentiment (Roethhsberger \& Dickson, 1964). One important element that affects citizenship behavior is task interdependence. Groups characterized by reciprocal interdependence display more citizenship behavior than groups with independence rule (Smith, Organ, \& Near, 1983). Reciprocal interdependence requires spontaneous mutual adjustment in order to effect coordination (Thompson, 1967), and promotes group cohesion (Seashore, 1954). Such requirement fosters social norms of cooperation, helping, and sensitivity to others' needs and makes salient a collective sense of social responsibility (Krebs, 1970). Organizations which promote social interaction among customers realize enhanced 
customer loyalty (Arnould, Price, \& Zinkhan, 2004; AubertGamet \& Cova, 1999; McAlexander et al., 2002; Muniz \& O'Guinn, 2001; Oliver, 1999; Schouten \& McAlexander, 1995). Since online brand communities encourage consumers to participate in reciprocal, interactive communications and activities (Nambisan \& Baron, 2007), which require high levels of task interdependence (Schau et al., 2009), it leads consumers to exhibit loyalty toward not only the focal brand (Muniz \& O'Guinn, 2001) but also the community (Krebs, 1970; Rosenbaum et al., 2005).

Value creation practices generated in online brand community may affect community loyalty since it provides members with social identity (Schau et al., 2009). As members participating in value creation practices, they accrue cultural capital, achieve social status, and develop social identity within the community. Such practices act as a significant switching cost, strengthen the community, and induce members to become more deeply engaged with the community (Schau et al., 2009). Therefore, the present study hypothesizes the mediating effects of community loyalty in a relationship between value creation practices and brand loyalty.

H3: Community loyalty will mediate the relationship between value creation practices and brand loyalty.

\section{Research Methodology}

Participants of this study are members of various types of online brand communities (e.g., business-to-consumer virtual product support community, firm-hosted online community, user-generated online community, peer-to-peer problem-solving community, and social media based brand community).

The total number of participants was 353. Data were collected online using Amazon Mechanical Turk from April 10, 2016 to May 10, 2016. After reading instructions and browsing provided links of online brand communities, participants were asked to answer; (a) whether they belong to online brand communities, (b) what is the name of the online brand community they associate themselves with, (c) how long they have been a member of the online brand community, and (d) how often they login to the online brand community on a daily, weekly, and monthly basis.

The average years that participants of this study have been a member of their online brand communities was 4.75 years. The average times participants of this study login to their online brand communities was, 3.74 times a day, 22.52 times a week, and 78.22 times a month. Although online brand community does not require the acquisition of the brand's product, 326 participants $(92.4 \%)$ answered that they own products made by the focal brand of their online brand community. The remained 27 participants (7.6\%) answered that they do not own the products. The number of female participants was $283(55.3 \%)$, and the number of male participants was 229 (44.7\%).

\section{Results}

The data were analyzed through structural equations modeling using AMOS 20. A two-step structural equation modeling approach (Anderson \& Gerbing, 1988) was used for the analysis. Mediating effects of community loyalty were tested by following Baron and Kenny's (1986) steps for mediation.

\subsection{Measurement Model}

Table 1: Measurement Model and Results

\begin{tabular}{|c|c|c|c|c|}
\hline & $\begin{array}{c}\text { Factor } \\
\text { Loading }\end{array}$ & $\begin{array}{l}\text { Cronbach's } \\
\text { Alpha }\end{array}$ & AVE & $\begin{array}{l}\text { Construct } \\
\text { Reliability }\end{array}$ \\
\hline ck1 & .97 & \multirow{2}{*}{.74} & \multirow{2}{*}{.61} & \multirow{2}{*}{.75} \\
\hline ck2 & .54 & & & \\
\hline rt1 & .80 & \multirow{2}{*}{.79} & \multirow{2}{*}{.65} & \multirow{2}{*}{.79} \\
\hline rt2 & .81 & & & \\
\hline $\mathrm{mr} 1$ & .76 & \multirow{2}{*}{.68} & \multirow{2}{*}{.52} & \multirow[b]{2}{*}{.69} \\
\hline $\mathrm{mr} 2$ & .68 & & & \\
\hline sn1 & .64 & \multirow{4}{*}{.77} & \multirow{4}{*}{.45} & \multirow{4}{*}{.77} \\
\hline sn2 & .71 & & & \\
\hline sn3 & .63 & & & \\
\hline sn4 & .70 & & & \\
\hline im1 & .74 & \multirow{2}{*}{.68} & \multirow{2}{*}{.52} & \multirow{2}{*}{.68} \\
\hline im2 & .70 & & & \\
\hline ce1 & .73 & \multirow{3}{*}{.80} & \multirow{3}{*}{.56} & \multirow{3}{*}{.80} \\
\hline $\mathrm{ce} 2$ & .78 & & & \\
\hline $\mathrm{ce} 3$ & .75 & & & \\
\hline bu1 & .79 & \multirow{2}{*}{.69} & \multirow{2}{*}{.54} & \multirow{2}{*}{.70} \\
\hline bu2 & .67 & & & \\
\hline bl1 & .78 & \multirow{4}{*}{.87} & \multirow{4}{*}{.62} & \multirow{4}{*}{.87} \\
\hline $\mathrm{bl} 2$ & .75 & & & \\
\hline $\mathrm{bl3}$ & .88 & & & \\
\hline bl4 & .73 & & & \\
\hline ci1 & .70 & \multirow{4}{*}{.84} & \multirow{4}{*}{.57} & \multirow{4}{*}{.84} \\
\hline ci2 & .83 & & & \\
\hline ci3 & .72 & & & \\
\hline ci4 & .78 & & & \\
\hline soc1 & .85 & \multirow{4}{*}{.91} & \multirow{4}{*}{.70} & \multirow{4}{*}{.91} \\
\hline soc2 & .86 & & & \\
\hline soc3 & .85 & & & \\
\hline soc4 & .80 & & & \\
\hline ocb1 & .65 & & & \\
\hline ocb2 & .73 & & & \\
\hline ocb3 & .75 & .81 & .52 & .81 \\
\hline ocb4 & .75 & & & \\
\hline
\end{tabular}


All measurement scales were derived from established studies; markers of online brand community (Laroche et al., 2012), social networking (Hsieh et al., 2005), impression management (Laroche et al., 2012), community engagement (Algesheimer, Dholakia, \& Herrmann, 2005), brand use (Laroche et al., 2012), community identification (Bagozzi \& Dholakia, 2006b; Hinkle et al., 1989), sense of community (Rosenbaum et al., 2005), organizational citizenship behavior (Podsakoff et al., 1990), brand loyalty (Chaudhuri \& Holbrook, 2001). All items in the model showed loadings greater than .50. All items and their associated factor loadings, Cronbach's alpha, AVE, and construct reliability are shown in Table 1.

Internal consistency and convergent validity of the constructs were confirmed by Cronbach's alpha with a minimum of .70 (Cronbach \& Furby, 1970; Nunnally, 1967), the average variance extracted (AVE) with a minimum of .50 (Fornell \& Larcker, 1981; Bagozzi \& Yi, 1988), and the construct reliability (C.R.) with a minimum of .70 (Fornell \& Larcker, 1981). Discriminant validity was achieved for all constructs. The square root of the average variance extracted for all constructs exceeded the correlation between two latent constructs (Fornell \& Larcker, 1981). The final measurement model exhibited satisfactory goodness-of-fit statistics (Bagozzi \& Yi, 1988); $X^{2}(456)=$ 911.136, $\mathrm{X}^{2} / \mathrm{df}=1.998, \mathrm{p}=.000, \mathrm{GFI}=.861, \mathrm{CFI}=.922$, RMSEA $=.053$.

\subsection{Structural Model}

The structural model $(\mathrm{N}=353)$ showed satisfactory goodness-of-fit statistics (Bagozzi \& Yi, 1988); $X^{2}(473)=$ $1001.541, \mathrm{X}^{2} / \mathrm{df}=2.117, \mathrm{p}=.000, \mathrm{GFI}=.840, \mathrm{CFI}=.909$, RMSEA $=.056$.

Hypotheses 1 and 2 were tested at the first stage. To test hypotheses 1 and 2, the community loyalty construct was excluded from the full model. The structural model that tested the relationship between online brand community, value creation practices, and brand loyalty showed satisfactory goodness-of-fit statistics (Bagozzi \& Yi, 1988); $\mathrm{X}^{2}(176)=428.751, \mathrm{X}^{2} / \mathrm{df}=2.436, \mathrm{p}=.000, \mathrm{GFI}=.895, \mathrm{CFI}$ $=.919$, RMSEA $=.064$.

Hypotheses 1 and 2 were supported. All paths in the model were significant at $p<0.001$ level (Table 2). All three markers of online brand community (e.g., consciousness of kind, rituals and traditions, and moral responsibility) were proved to be a significant indicator of the online brand community. Hypothesis 1 was supported. As a consequence of the linear sum of three community markers, the online brand community showed significant effects on the value creation practices $(\beta=.850)$. Among the three community markers, moral responsibility showed the strongest effect on the online brand community $(\beta=.841)$. The standardized regression weights of consciousness of kind and rituals and traditions markers on the online brand community were .634 and .622 , respectively.

All four value creation practices were proved to be a significant indicator of the value creation practices construct. Among the four practices, social networking $(\beta=.966)$, impression management $(\beta=.995)$, and brand use $(\beta$ $=$.921) practices showed strong effects on value creation practices. Community engagement practice $(\beta=.776)$ showed the weakest effects on value creation practices. Hypothesis 2 was supported. The value creation practices showed significant effects on brand loyalty $(\beta=.809)$.

Table 2: Results of Testing: Hypothesis 1, 2

\begin{tabular}{|c|c|c|c|}
\hline & Path & Coefficient & C.R \\
\hline \multirow{4}{*}{$\mathrm{H} 1$} & $\begin{array}{l}\text { Consciousness of Kind } \\
\rightarrow \text { Online Brand Community }\end{array}$ & .634 & ** \\
\hline & $\begin{array}{l}\text { Rituals and Traditions } \\
\rightarrow \text { Online Brand Community }\end{array}$ & .622 & $* * 5.135$ \\
\hline & $\begin{array}{l}\text { Moral Responsibility } \\
\rightarrow \text { Online Brand Community }\end{array}$ & .841 & $* * 5.246$ \\
\hline & $\begin{array}{l}\text { Online Brand Community } \\
\rightarrow \text { Value Creation Practices }\end{array}$ & .850 & **5.202 \\
\hline \multirow{5}{*}{$\mathrm{H} 2$} & $\begin{array}{l}\text { Value Creation Practices } \\
\rightarrow \text { Social Networking }\end{array}$ & .966 & ** \\
\hline & $\begin{array}{l}\text { Value Creation Practices } \\
\rightarrow \text { Impression Management }\end{array}$ & .995 & $* * 10.157$ \\
\hline & $\begin{array}{l}\text { Value Creation Practices } \\
\rightarrow \text { Community Engagement }\end{array}$ & .776 & **9.312 \\
\hline & $\begin{array}{l}\text { Value Creation Practices } \\
\rightarrow \text { Brand Use }\end{array}$ & .921 & **10.886 \\
\hline & $\begin{array}{l}\text { Value Creation Practices } \\
\rightarrow \text { Brand Loyalty }\end{array}$ & .809 & ${ }^{* *} 9.797$ \\
\hline
\end{tabular}

Notes: ${ }^{* *} p<.001$

Hypothesis 3, the mediating effects of community loyalty on the relationship between value creation practices and brand loyalty, was tested at the second stage. The mediating effects of community loyalty were tested by following Baron and Kenny's (1986) steps for mediation. Since the effects of value creation practices on brand loyalty $(\mathrm{H} 2)$ were revealed at the first stage, the effects of value creation practices on community loyalty were tested to satisfy the preliminary conditions of mediating effects suggested by Baron and Kenny (1986).

To test the effects of value creation practices on community loyalty, the brand loyalty construct was excluded from the full model. The structural model that tests the 
preliminary condition of mediating effects showed satisfactory goodness-of-fit statistics (Bagozzi \& Yi, 1988); $\mathrm{X}^{2}(361)=835.754, \mathrm{X}^{2} / \mathrm{df}=2.315, \mathrm{p}=.000, \mathrm{GFI}=.845, \mathrm{CFI}$ $=.901$, RMSEA $=.061$.

Since community loyalty was operationalized as a second-order reflective latent construct with the three firstorder reflective indicators (e.g., community identification, sense of community, and organizational citizenship behavior), the significance of indicators was tested before testing the relationship between value creation practices and community loyalty. The results showed that all the three indicators were significant reflective indicators of community loyalty at $p<.001$ level. Among the three indicators, community identification $(\beta=.811)$ and organizational citizenship behavior $(\beta=.874)$ showed strong effects, and the sense of community $(\beta=.353)$ showed relatively weaker effects on community loyalty (Table 3 ). The effects of value creation practices on community loyalty $(\beta=.879)$ were confirmed at $p<.001$ level, which satisfies the preliminary conditions to proceed to test the mediating effects of community loyalty.

The mediating effects of community loyalty on the relationship between value creation practices and brand loyalty were tested with the full model $\left(\mathrm{X}^{2} / \mathrm{df}=2.117\right.$, GFI $=.840, \mathrm{CFI}=.909$, RMSEA $=.056)$. In the previous stage, the two preliminary conditions for testing the mediating effects of community loyalty were confirmed. Value creation practices showed significant effects on both brand loyalty and community loyalty, respectively. However, when the community loyalty construct was included as a mediator between the two constructs, value creation practices and brand loyalty, the effects of value creation practices on brand loyalty dropped in magnitude, from $.809(p<.001)$ to $-.248(p=.22)$, and the relationship became non-significant. Therefore, hypothesis 3 was supported. The standardized regression weights for each path are presented in Table 3 and Figure 1.

Table 3: Results of Testing: Hypothesis 3

\begin{tabular}{|c|l|c|c|}
\hline & \multicolumn{1}{|c|}{ Path } & Coefficient & C.R \\
\hline \multirow{4}{*}{ H3 } & $\begin{array}{l}\text { Value Creation Practices } \\
\rightarrow \text { Brand Loyalty }\end{array}$ & -.248 & -1.238 \\
\cline { 2 - 4 } & $\begin{array}{l}\text { Value Creation Practices } \\
\rightarrow \text { Community Loyalty }\end{array}$ & .982 & $* * 9.543$ \\
\cline { 2 - 4 } & $\begin{array}{l}\text { Community Loyalty } \\
\rightarrow \text { Brand Loyalty }\end{array}$ & .924 & $\begin{array}{c}1.990 \\
(p=.05)\end{array}$ \\
\hline
\end{tabular}

Notes: ${ }^{* *} p<.001$

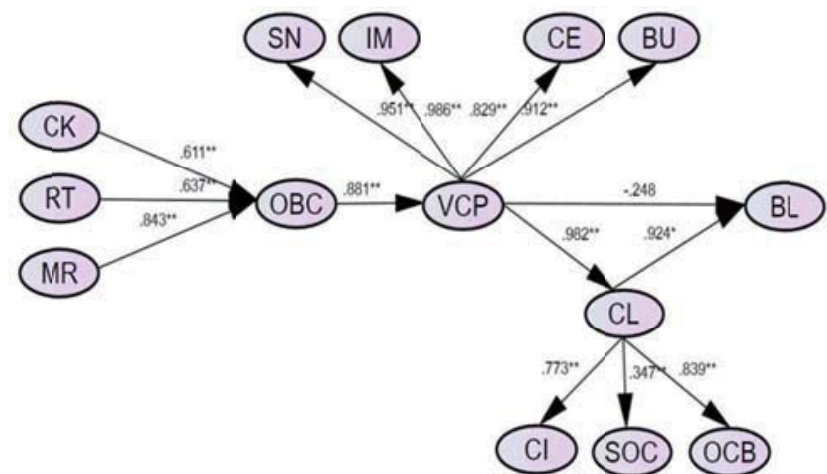

Figure1: Results of Testing: Hypothesis 3

\section{Discussions and Conclusions}

This study modeled the online brand community as a reflective first-order, formative second-order construct. The test results showed that all the three community markers are significant indicators of the online brand community $(p<0.001)$. The results suggest that the online brand community strengthens when; (a) members feel and recognize consciousness of kind with other members, (b) rituals and traditions of online brand community strengthen, and (c) members feel a sense of duty to the community and individual members.

The moral responsibility marker showed the strongest effects on the online brand community. This study showed that although the online brand community is a voluntary group, there exists moral consciousness among members both to the community and individual members. Such findings are meaningful in that it reveals the distinctive features of online brand community, compare to traditional brand communities. In previous brand community research, it has been believed that consciousness of kind is the most effective marker among the three community markers (Muniz \& O'Guinn, 2001). Wirtz et al.'s (2013) also pointed that online brand community members tend to carry less moral responsibility since online brand community allows members to reveal only little of their identity. However, this study empirically revealed that the moral responsibility marker has the strongest effects on the online brand community.

Assisting members in the proper use of the focal brand is one of the most representative forms of moral responsibility shown in brand communities. In traditional, offline brand communities, assisting or helping other members are not easy to be manifested because those activities frequently go beyond members' formal role. Unlike consciousness of kind and rituals and traditions markers, it requires altruistic 
motivation of members for moral responsibility being manifested in brand communities. It also requires more investments in terms of members' time and effort. For those reasons, in traditional, offline brand communities, the moral responsibility has a relatively weaker effect on brand communities. However, in online brand communities, assisting or helping other members regarding the use of the focal brand could be easily manifested, since assisting or helping behaviors can be institutionalized and regenerated in the online brand communities. Most of the communications generated in the online brand community are centered on consumption experiences of using the focal brand. Online brand communities accumulate expertise on individual topics related to the focal brand, and those accumulated expertise function as a cultural capital for consumers who seek for reliable consumption-related information. Considering the significant effects that the moral responsibility marker has on the online brand community, marketers should facilitate online brand community members to discuss or share consumptionrelated information with each other in the communities.

In testing the effects of online brand community, this study measured the online brand community as a sum of three community markers; consciousness of kind, rituals and traditions, and moral responsibility. Since this study modeled the online brand community as a reflective firstorder, formative second-order construct, the value creation practice of online brand community was simultaneously modeled as an outcome of the latent variable. The test results of hypothesis 1 showed that the online brand community has significant effects on the value creation practices of online brand community. All four value creation practices were proved to be a significant reflective indicator of the value creation practice construct.

Hypothesis 2 tested the effects of value creation practices on brand loyalty. The tested results showed that value creation practices of online brand community enhance brand loyalty. Such finding aligns with previous brand community research showing that a strong brand community can lead members to have not only a socially embedded loyalty but also a hyper-loyalty (Muniz \& O'Guinn, 2001).

Hypothesis 3 was supported. In testing the community loyalty construct, this study defined the community loyalty based on the two of closely related loyalty, group loyalty and organizational loyalty, and measured the community loyalty as it consists of cognitive, affective, and behavioral dimensions of loyalty. Community identification, sense of community, and organizational citizenship behavior were modeled as reflective indicators of the community loyalty. The test results showed that all three indicators are significant reflective indicators of the community loyalty. This study found that community loyalty fully mediates the relationship between the value creation practice and brand loyalty. The mediating effects of community loyalty suggest that making members loyal to the community is crucial to gain brand-loyal customers.

\section{Limitations and Direction for Future Research}

There are some limitations in this research. First, this study does not differentiate data according to the product categories. Since the aim of this study is to test the effects of online brand community in general, this study does not investigate the effects of product categories on the online brand community. In this study, the data heterogeneity issue regarding a product category was only confirmed by conducting a group comparison between high and low product involvement groups. However, since this study revealed the effects of online brand community in general, future research should narrow down the scope of online brand community research by investigating the online brand community of specified product category.

Second, the effects of online brand community on its outcomes could be different according to the governance of the community. For example, online brand communities generated by devoted users of the brand may show distinctive outcomes compare to online brand communities generated by firms or marketers. Therefore future research should investigate the impact of various moderators, such as governance, on online brand communities.

\section{References}

Algesheimer, R., Dholakia, U.M., \& Herrmann, A. (2005). The social influence of brand community: Evidence from European car clubs. Journal of Marketing, 69(3), 19-34.

Anderson, J. C., \& Gerbing, D. W. (1988). Structural equation modeling in practice: $A$ review and recommended two-step approach. Psychological Bulletin, 103(3), 411-423.

Arnould, E. J., Price, L. L., \& Zinkhan, G. L. (2004). Consumers (2nd ed.). New York: McGraw-Hill/Richard D. Irwin.

Arrow, H., McGrath, J. E., \& Berdahl, J. L. (2000). Small groups as complex systems. London: Sage.

Aubert-Gamet, V., \& Cova, B. (1999). Servicescapes: From modern non-places to postmodern commonplaces. Journal of Business Research, 44(1), 37-45.

Bagozzi, R. P., \& Dholakia, U. M. (2002). Intentional social action in virtual communities. Journal of Interactive Marketing, 16(2), 2-21. 
Bagozzi, R. P., \& Dholakia, U. M. (2006a). Antecedents and purchase consequences of customer participation in small group brand communities. International Journal of Research in Marketing, 23(1), 45-61.

Bagozzi, R. P., \& Dholakia, U. M. (2006b). Open source software user communities: A study of participation in Linux user groups. Managament Science, 52(7), 10991150.

Bagozzi, R., \& Yi, Y. (1988). On evaluation of structural equation models. Journal of the Academy of Marketing Science, 16, 74-94.

Baron, R. M., \& Kenny, D. A. (1986). The moderatormediator variable distinction in social psychological research: Conceptual, strategic, and statistical considerations. Journal of Personality and Social Psychology, 51(6), 1173-1182.

Bourdieu, P. (1984). Distinction: A social critique of the judgment of taste. Cambridge, MA: Harvard University Press.

Brewer, M. B., \& Brown, R. J. (1998). Intergroup relations. In D. T. Gilbert, S. T. Fiske, \& G. Lindzey (Eds.), The handbook of social psychology (pp. 554-594). Boston, MA: McGraw-Hill.

Brodie, R. J., Ilic, A., Juric, B., \& Hollebeek, L. (2013). Consumer engagement in a virtual brand community: An explanatory analysis. Journal of Business Research, 66, 105-114.

Carroll, B. A., \& Ahuvia, A. C. (2006). Some antecedents and outcomes of brand love. Marketing Letters, 17, 79-89.

Chaudhuri, A., \& Holbrook, M. B. (2001). The chain of effects from brand trust and brand affect to brand performance: The role of brand loyalty. Journal of Marketing, 65(2), 81-93.

Cronbach, L. J., \& Furby, L. (1970). How we should measure "change" - or should we? Psychological Bulletin, 74(1), 68-80.

Dawes, R. M., Van de Kragt, A. J. C., \& Orbell, J. M. (1990). Cooperation for the benefit of us-Not me, or my conscience. In J. J. Mansbridge (Ed.), Beyond selfinterest (pp. 97-100). Chicago, IL: Univ. of Chicago Press.

De Valck, K., Van Bruggen, G., \& Wierenga B. (2009). Virtual communities: A marketing perspective. Decision Support Systems, 47, 185-203.

Fornell, C., \& Larker, D. F. (1981). Evaluating structural equation models with unobserved variables and measurement error. Journal of Marketing Research, 3950.

Gusfield, J. (1978). Community: A critical response. New York, NY: Harper and Row.

Hinkle, S., Taylor, L. A., Fox-Cardamone, L., \& Crook, K. F. (1989). Intragroup identification and intergroup identification: A multicomponent approach. British Journal of Social Psychology, 28, 305-317.

Hogg, M., \& Savolainen, M. (1997, October). The role of aversion in product/brand choice. Paper presented at the Association for Consumer Research Conference, Denver, CO.

Holt, D. B. (1997). Poststructuralist lifestyle analysis: Conceptualizing the social patterning of consumption in postmodernity. Journal of Consumer Research, 23, 326350.

Hsieh, Y., Chiu, H., \& Chiang, M. (2005). Maintaining and committed online customer: A study across searchexperience-credence products. Journal of Retailing, 81, 75-82.

Jarvis, C. B., Mackenzie, S. B., \& Podsakoff, P. M. (2003). A critical review of construct indicators and measurement model misspecification in marketing and consumer research. Journal of Consumer Research, 30(2), 199-218.

Krebs, D. L. (1970). Altruism; An examination of the concept and a review of the literature Psychological Bulletin, 73, 258-302.

Laroche, M., Habibi, M. R., Richard, M. O., \& Sankaranarayanan, R. (2012). The effects of social media based brand communities on brand community markers, value creation practices, brand trust and brand loyalty. Computers in Human Behavior, 28, 1755-1767.

Lave, J., \& Wenger, E. (1991). Situated learning: Legitimate peripheral participation. Cambridge, UK: Cambridge University Press.

Levine, J. M., \& Moreland, R. L. (2002). Group reactions to loyalty and disloyalty. In E. Lawler \& S. Thye (Eds.), Group cohesion, trust, and solidarity: Advances in group processes, Vol.19 (pp.203-228). Amsterdam: Elsevier Science.

McAlexander, J. H., Schouten, J. W., \& Koenig, H. F. (2002). Building brand community. Journal of Marketing, 66, 3854.

McMillian, D. W., \& Chavis, D. M. (1986). Sense of community: A definition and theory. Journal of Community Psychology, 14(1), 6-23.

Muniz, A. M. Jr., \& O'Guinn, T. C. (2001). Brand community. Journal of Consumer Research, 27(4), 412-432.

Nambisan, S., \& Baron, R. A. (2007). Interactions in virtual customer environments: Implications for product support and customer relationship management. Journal of Interactive Marketing, 21(2), 42-62.

Nunnally, J. (1967). Psychometric methods. New York, NY: McGraw-Hill.

Oliver, R. L. (1999). Whence consumer loyalty? Journal of Marketing, 63, 33-44. 
Organ, D. W. (1988). Organizational citizenship behavior: The good soldier syndrome. Lexington, MA: Lexington Books.

Podsakoff, P. M., Mackenzie, S. B., Moorman, R. H., \& Fetter, R. (1990). Transformational leader behaviors and their effects on followers' trust in leader, satisfaction, and organizational citizenship behaviors. Leadership Quarterly, 1(2), 107-142.

Roethhsberger, F. J., \& Dickson, W. J. (1964). Management and the worker. New York, NY: Wiley Science Editions.

Rosenbaum, M. S., Ostrom, A. L., \& Kuntze, R. (2005). Loyalty programs and a sense of community. Journal of Services Marketing, 19(4), 222-233.

Schau, H. J., Muniz, A. M., Jr., \& Arnould, E. J. (2009). How brand community practices create value. Journal of Marketing, 73, 30-51.

Schouten, J. W., \& McAlexander, J. H. (1995). Subcultures of consumption: An ethnography of the new bikers. Journal of Consumer Research, 22, 43-61.

Seashore, S E. (1954). Group cohesiveness in the industrial work group. Ann Arbor, MI: University of Michigan Press.

Smith, C. A., Organ, D. W., \& Near, J. P. (1983). Organizational citizenship behavior: Its nature and antecedents. Journal of Applied Psychology, 68(4), 653663.

Tajfel, H., \& Turner, J. C. (1986). The social identity theory of intergroup behavior. In S. Worchel \& W. Austin (Eds.), Psychology of intergroup relations (pp.7-24). Chicago, IL: Nelson-Hall.

Thompson, J. D. (1967). Organizations in action. New York, NY: McGraw-Hill.

Van Vugt, M., \& Hart, C. M. (2004). Social identity as social glue: The origins of group loyalty. Journal of Personality and Social Psychology, 86(4), 585-598.

Weber, M. (1978). Economy and society. Berkeley, CA: University of California Press.

Wilder, D. A. (1986). Social categorization: Implications for creation and reduction of intergroup bias. In L. Berkowitz (Ed.), Advances in experimental social psychology, Vol. 19 (pp. 291-355). New York, NY: Academic Press.

Wirtz, J., Ambtman, A., Bloemer, J., Horvath, C., Ramaseshan, B., Klundert, J, Canli, Z. G., \& Kandampully, J. (2013). Managing brands and customer engagement in online brand communities. Journal of Service Management, 24(3), 223-344. 